\title{
Effects of wastewater applied with discrete irrigation techniques on strawberry plants' productivity and the safety, quality characteristics and antioxidant capacity of fruits
}

\author{
Anastasis Christou ${ }^{\mathrm{a}, *}$, Grivas Maratheftis ${ }^{\mathrm{a}}$, Michael Elia ${ }^{\mathrm{a}}$, Evroula Hapeshi ${ }^{\mathrm{b}, \mathrm{c}}$, \\ Costas Michael $^{\text {b,c }}$, Despo Fatta-Kassinos ${ }^{\text {b,c }}$ \\ a Agricultural Research Institute, P.O. Box 22016, 1516 Nicosia, Cyprus \\ b Department of Civil and Environmental Engineering, University of Cyprus, P.O. Box 20537, 1678 Nicosia, Cyprus

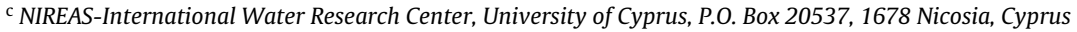

\section{A R T I C L E I N F O}

\section{Article history:}

Received 12 January 2016

Received in revised form 25 April 2016

Accepted 29 April 2016

Available online 9 May 2016

\section{Keywords:}

Antioxidant capacity

Escherichia coli

Heavy metal content

Microbial assay

Sprinkler irrigation

Wastewater reuse

\begin{abstract}
A B S T R A C T
Water scarcity renders wastewater (WW) reuse for irrigation an increasingly common practice worldwide. Comprehensive guidelines and criteria have been established to secure the safety of WW irrigation, especially for food crops or crops that are eaten raw. The aim of this short-term study was to assess the impacts of strawberry crop irrigation with tertiary treated wastewater (WW) using common irrigation techniques (Drip, sprinkler, drip under plastic mulch), as compared to potable water (PW) irrigation, on strawberry fruits' quality and safety, and on crops' productivity. The impacts on fruits' weight and marketability, as well as on fruits' taste (soluble solids, titratable acidity and soluble solids/titratable acidity ratio), antioxidant capacity (ascorbic acid concentration, FRAP, total phenolics and total anthocyanin content), heavy metal content ( $\mathrm{Cu}, \mathrm{Zn}, \mathrm{Mn}, \mathrm{Co}, \mathrm{Ni}$ ) and microbial contamination (total coliform, E. coli, Salmonella spp., Listeria spp), were evaluated. The results revealed that WW irrigation did not significantly affect the fruits' marketability, taste and antioxidant capacity, as well as the heavy metal content, in comparison to controlled irrigation, regardless of the irrigation technique applied. Fruits heavy metal content was found to be below the maximum permissible levels (MPLs) set for fruit safety, whereas no microbiological contamination (total coliform, E. coli, Salmonella spp., Listeria spp.) of fruits was found in all irrigation water treatments. Overall, the results obtained with regard to the parameters examined highlight the potential for the reuse of the advanced tertiary treated effluent of good quality as a valid alternative for the irrigation of strawberry crops, even with sprinklers. However, further long-term studies are needed in order for such a practice to be regulated.
\end{abstract}

(c) 2016 Elsevier B.V. All rights reserved.

\section{Introduction}

Diminishing availability of good quality agricultural water due to climate change effects and escalating competition from other water use sectors (Mesa-Jurado et al., 2012; Milano et al., 2012), renders treated wastewater (WW) a valuable alternative source of irrigation water (Hamilton et al., 2007). Wastewater is a nutrientreach water resource that may be constantly supplied for the mitigation of irrigation water imbalances in agricultural sites in arid and semi-arid areas around the world (Bahri, 1999; Chu et al., 2004; Bixio et al., 2006; Angelakis and Durham, 2008; Khurana and Singh, 2012). However, WW should be reused with caution and regularly monitored, as it may contain chemical and biological

\footnotetext{
* Corresponding author.

E-mail address: anastasis.christou@ari.gov.cy (A. Christou).
}

contaminants and pollutants that may pose negative environmental and health impacts (Singh et al., 2004; Hamilton et al., 2006a; Muchuweti et al., 2006; Fatta-Kassinos et al., 2011). Over the last decade, a fairly large body of literature has revealed that WW reuse for irrigation, along with the use of sewage sludge as soil amendment, may result to the contamination of soils with heavy metals and other pollutants, with their subsequent entrance into the food chain to be of great concern (Li et al., 2009; Xu et al., 2010; Rajaganapathy et al., 2011). Crop plants irrigated with raw WW or insufficiently treated or industrial WW have been found to absorb and accumulate heavy metals in their edible parts beyond the maximum permissible limits (MPLs) (Mapanda et al., 2005; Muchuweti et al., 2006; Khan et al., 2008; Singh et al., 2010; Hashem et al., 2013), evoking concerns of potential negative impacts on public health (Adam and Kizek, 2012; Szkup-Jablonska et al., 2012). On the other hand, agricultural produce harvested from plants irrigated with advance tertiary treated WW have been found to be 
safe for consumption, as far their heavy metal content (Christou et al., 2014b; Al-Lahham et al., 2007). Moreover, the reuse of raw or insufficiently treated WW, rather than advanced treated WW, for irrigation of crop plants, accompanied with improper agricultural practices, may result to the contamination of agricultural produce with microbial and other anthropogenic pathogens, such as Escherichia coli, Salmonella spp. Listeria spp, Giardia spp, etc. (Petterson et al., 2001; Palese et al., 2009; Bernstein, 2011; Cirelli et al., 2012). Thus, microbial risks assessment techniques have been developed to estimate the human health risks associated with the use of wastewater for unrestricted and restricted crop irrigation, simultaneously facilitating the establishment of acceptable levels of microbial contaminants in treated effluents (Hamilton et al., 2006b; Mara et al., 2007; Mok et al., 2014).

From the agronomic point of view, WW irrigation was found to affect the yield and the quality attributes of agricultural produce, as WW may contain considerable nutrient and heavy metal content, depending on sewage origin and treatment technology applied. Irrigation of tomato plants with advance treated WW was found to increase the size and weight of fruits, as well as decrease their firmness and weight loss (Al-Lahham et al., 2003). On the contrary, Christou et al., 2014b) reported no important effects of tertiary treated WW irrigation on tomato fruits weight, maximum diameter and total number of fruits harvested. Low quality industrial WW was found to decrease the dry matter yield and photosynthetic pigments of lettuce plants, while also increase the activity of antioxidant enzymes and the content of antioxidant molecules (carotenoids) (Naaz and Pandey, 2010).

Towards the mitigation or even the elimination of all possible hazards from excreta-related pathogens and some toxic elements due to WW reuse in agriculture, well exhaustive guidelines and criteria have been established (WHO, 2006; Brissaud, 2008; US Environmental Protection Agency, 2012). Health protection measures that have an impact on wastewater-irrigated produce or to the consumers include WW treatment procedures (tertiary treatment and disinfection), WW application techniques (drip or subsurface irrigation), etc. Wastewater irrigation of food crops is prohibited in many countries, whereas in some others is conditionally allowed (US Environmental Protection Agency, 2012). In Cyprus, a semi-arid Mediterranean country that faces long-term water imbalances, WW reuse in agriculture is a well established-practice. Currently, 22 million cubic meters (MCM) of tertiary-treated WW per year is being reused for irrigation and aquifer recharge, regulated by a comprehensive guideline and a code of good agricultural practice (Christou et al., 2014a). According to the Cypriot guidelines, WW can be reused for the irrigation of all crops (given that the code of good agricultural practice is implemented), with the sole exception of leafy vegetables, and bulbs and tubers that are eaten raw. Within the frames of these guidelines, strawberry crops are allowed to be drip and subsurface irrigated with WW, as fruits are not coming in direct contact with WW. However, a vigorous debate about the safety of strawberry fruits produced from wastewater-irrigated crops is taking place among consumers and growers. A holistic approach was employed in this study with the aim to assess the impacts of strawberry plants WW irrigation with various irrigation techniques (drip, sprinkler, drip under plastic mulch) on fruits' safety and quality, and crop productivity.

\section{Materials and methods}

\subsection{Experimental design and treatments}

Young strawberry transplants (Fragaria $\times$ ananassa cv. camarosa) were planted in 9-L plastic pots filled with potting soil (pH 5.34, EC $0.32 \mathrm{mS} \mathrm{cm}^{-1}$, $\mathrm{N} 150 \mathrm{mg} \mathrm{L}^{-1}, \mathrm{P}_{2} \mathrm{O}_{5} 185 \mathrm{mg} \mathrm{L}^{-1}, \mathrm{~K}_{2} \mathrm{O}$ $250 \mathrm{mg} \mathrm{L}^{-1}$ ) and grown in greenhouse at the Cyprus Agricultural Research Institute in Nicosia for 75 days during the period of late February to early May 2015. The average climatic conditions in the greenhouse during the experimental period were $29 / 13^{\circ} \mathrm{C}$ mean day/night temperature and $25-50 \%$ relative humidity. Plants were irrigated based on their water needs with either potable water (PW) or with WW transported from the Anthoupoli WW treatment plant in Nicosia and stored in 300-L stainless steel tank. The treated WW used in this study was tertiary treated (by a membrane bioreactor) and disinfected (by UV treatment). The chemical and microbial load of the two water sources applied for the irrigation of strawberry plants is presented in Table 1. Soluble fertilizer was applied once a week to satisfy the plants nutrients needs, whereas excess irrigation was practiced also once weekly in order for drainage to occur and salt leaching to be achieved. Overall, strawberry plants were subjected to six treatments, based on the water source (PW, WW) and the technique (drip, sprinkler, drip under plastic mulch) applied for their irrigation. More precisely, plants in PW-DR and WW-DR treatments were drip irrigated with $\mathrm{PW}$ and WW, respectively; plants in PW-SPR and WW-SPR treatments were irrigated with sprinkles using PW and WW, respectively; whereas, plants in PW-DRPM and WW-DRPM treatments were drip irrigated with PW and WW, respectively, with the dripping tube and soil being covered with plastic mulch. Surface drip irrigation or drip irrigation under plastic mulch are the most commonly used techniques for strawberry crops' WW irrigation in Cyprus, while sprinkler irrigation is prohibited as fruits come to direct contact with WW, and used to simulate the worst case scenario. The use of pots and plastic mulch for covering the soil and dripping tubes employed in this study is representative of the strawberry crop cultivation both in field, as well as under hydroponic cultivation, an increasingly practiced approach worldwide. Worth noting, WW irrigation in hydroponic strawberry cultivation is already a common practice in Cyprus. A completely randomized block design was applied, while each treatment was independently run in triplicates; each replicate consisted of 6 individual strawberry plants. As a result, 108 strawberry plants were used in this experiment.

\subsection{Sample collection and preparation}

Strawberry fruits were harvested at the fully red-ripe stage at four harvests during the last two weeks of the experimental period. Fruits collected in each harvest (four harvests took place at 62, 64,70 and 76 days after the initiation of the experiment) constituted the sample replications of each treatment (4 replicates in each treatment). Fruits were separated based on their marketability (marketable or not) and all fruits were weighed to obtain their fresh mass. Unmarketable fruits were characterized by malformation, various defects, or a weight lower than $13 \mathrm{~g}$. Ten marketable fruits from each treatment replicate were dried until constant weight in a preheated oven at $80^{\circ} \mathrm{C}$ for $72 \mathrm{~h}$, in order to calculate the percentage of dry matter (DM\%). Then, dried fruits were ground, sieved (30 mesh) and the content of heavy metals ( $\mathrm{Mn}, \mathrm{Co}, \mathrm{Cu}, \mathrm{Zn}, \mathrm{Ni}$ ) was estimated. Half of the remaining fresh fruits were immediately placed into polyethylene sterile bags and transferred to the laboratory for the microbiological assays, while the rests were stored at $-20^{\circ} \mathrm{C}$ till the analysis of their quality characteristics and antioxidant capacity. Heavy metal determination in fruits was based upon the concentrations of heavy metals quantified in the WW applied for strawberry plants' irrigation (Table 1 ), since various other heavy metals ( $\mathrm{Cd}, \mathrm{Pb}, \mathrm{Hg}, \mathrm{Cr}$ ) were below the limit of quantification. 
Table 1

Physico-chemical and microbiological analysis of the two water sources (potable water and wastewater) used for the irrigation of the strawberry crop.

\begin{tabular}{|c|c|c|c|}
\hline Parameter & Potable water & Wastewater & Irrigation water quality guidelines ${ }^{\mathrm{c}}$ \\
\hline $\mathrm{pH}$ & $8.30 \pm 0.02$ & $8.31 \pm 0.04$ & $6.50-8.40$ \\
\hline $\mathrm{EC}\left(\mathrm{mS} \mathrm{cm}^{-1}\right)$ & $0.67 \pm 0.02$ & $1.56 \pm 0.03$ & $0.70<\mathrm{a} / 0.70-3.00^{\mathrm{b}}$ \\
\hline $\mathrm{BOD}_{5}\left(\mathrm{mg} \mathrm{O}_{2} \mathrm{~L}^{-1}\right)$ & $\mathrm{ND}^{\mathrm{d}}$ & $3.58 \pm 0.21$ & \\
\hline $\operatorname{COD}\left(\mathrm{mg} \mathrm{O}_{2} \mathrm{~L}^{-1}\right)$ & ND & $30.52 \pm 1.23$ & \\
\hline $\mathrm{SS}\left(\mathrm{mg} \mathrm{L}^{-1}\right)$ & ND & $3.06 \pm 0.45$ & $<50.00^{\mathrm{a}}$ \\
\hline Total $\mathrm{N}\left(\mathrm{mg} \mathrm{L}^{-1}\right)$ & $0.93 \pm 0.11$ & $6.07 \pm 1.19$ & \\
\hline Total $\mathrm{P}\left(\mathrm{mg} \mathrm{L}^{-1}\right)$ & ND & $0.70 \pm 0.27$ & \\
\hline $\mathrm{Cl}^{-}\left(\mathrm{mg} \mathrm{L}^{-1}\right)$ & $87.24 \pm 2.63$ & $317.70 \pm 18.54$ & \\
\hline $\mathrm{Zn}\left(\mathrm{mg} \mathrm{L}^{-1}\right)$ & ND & $0.042 \pm 0.008$ & 2.00 \\
\hline $\operatorname{Mn}\left(\mathrm{mg} \mathrm{L}^{-1}\right)$ & ND & $0.023 \pm 0.006$ & 0.20 \\
\hline $\mathrm{Ni}\left(\mathrm{mg} \mathrm{L}^{-1}\right)$ & ND & $0.011 \pm 0.003$ & 0.20 \\
\hline $\mathrm{Cu}\left(\mathrm{mg} \mathrm{L}^{-1}\right)$ & ND & $0.016 \pm 0.004$ & 0.20 \\
\hline $\mathrm{Co}\left(\mathrm{mg} \mathrm{L}^{-1}\right)$ & ND & $0.013 \pm 0.002$ & 0.05 \\
\hline $\mathrm{Cd}\left(\mathrm{mg} \mathrm{L}^{-1}\right)$ & ND & ND & \\
\hline $\mathrm{Pb}\left(\mathrm{mg} \mathrm{L}^{-1}\right)$ & ND & ND & \\
\hline $\mathrm{Hg}\left(\mathrm{mg} \mathrm{L}^{-1}\right)$ & ND & ND & \\
\hline $\mathrm{Cr}\left(\mathrm{mg} \mathrm{L}^{-1}\right)$ & ND & ND & \\
\hline E. coli $\left(\mathrm{cfu} 100 \mathrm{ml}^{-1}\right)$ & ND & ND & \\
\hline Helminth eggs $\left(\operatorname{egg~L^{-1}}\right)$ & ND & ND & \\
\hline
\end{tabular}

Data are the mean values \pm standard error (SE) of 3 samples taken during the experimental period.

a no restrictions.

b slight to moterate restrictions for use for irrigation.

c As set by the FAO's water quality for agriculture report (Ayers and Westcot, 1985).

d Not detected or in the range of $\leq 1 \mu \mathrm{g} \mathrm{L}^{-1}$ for heavy metals' concentration.

\subsection{Analytical methods and measurements}

The $\mathrm{pH}$ and electrical conductivity (EC) of the PW and WW used for irrigation in this study were estimated using a $\mathrm{pH}$ meter (Orion 4 Star; Thermo Scientific, Waltham, USA) and an electrical conductivity meter (Hanna HI4321 benchtop elecrical conductivity meter; Woonsocket, USA), respectively. In addition, the COD and $\mathrm{BOD}_{5}$ of the WW was determined by the APHA 5220B method, using the Merck $^{\circledR}$ Spectroquant Kits (WTW Photolab S6, Merck, Darmstadt, Germany) and the APHA 5210A method, using the 444.406 OxiDirec apparatus (PCE GmbH, Meschede, Deutschland) (APHA, 1998), respectively. The Escherichia coli and helminths eggs were determined as described in APHA's standard method for the examination of water and WW. Heavy metals ( $\mathrm{Mn}, \mathrm{Co}, \mathrm{Cu}, \mathrm{Zn}, \mathrm{Ni}$ ) concentrations in both the irrigation water sources and the fruit samples were determined as previously described (Christou et al., 2014b). The microbiological examination of the fruits was performed on both non-washed harvested fruits as well as on well-washed with tap water fruits, and included the aerobic plate count (APC)(Hydrophobic Grid Membrane Filter Method, AOAC official method 986.32) and the quantification of total coliform (TC) in their homogenate (AOAC, 2005). The presence of Escherichia coli in fruit homogenates was assessed following the AOAC official method 2004.03 (AOAC, 2005). In addition, the presence of Salmonella spp. and Listeria spp. in the strawberry fruit homogenate was evaluated using the AOAC approved kits of Neogen Corporation (Neogen Corporation Inc, Miami, USA), as per the manufacturer instructions.

Soluble solids (SS) concentration was determined in the homogenized fruit sample by a refractometer (Atago PR-1, Tokyo, Japan) and expressed as ${ }^{0}$ Brix. The titratable acidity (TA) was measured by mixing $10 \mathrm{~g}$ of the pulp with $124 \mathrm{~mL}$ distilled water and titrating with $0.1 \mathrm{~N} \mathrm{NaOH}$ ( $\mathrm{pH} 8.1$ ), and expressed as\% citric acid. The $\mathrm{pH}$ value of the fruits was measured in the previous homogenate with a pH meter (Orion 4 Star; Thermo Scientific, Waltham, USA). Ascorbic acid content was estimated by using Reflectoquant ascorbic acid test strips in a RQflex reflectometer (Merck, Darmstadt, Germany) and results were expressed as mg ascorbic acid (ASC) $100 \mathrm{~g}^{-1}$ fresh weight (FW). Total anthocyanin content was estimated as mg pelargonidin-3-glucoside ( $\mathrm{P}-3-\mathrm{G}$ ) equivalents $100 \mathrm{~g}^{-1}$ FW using a molar absorptivity coefficient of 36000 , as proposed by Cordenunsi et al. (2003). For the estimation of total phenolics and ferric-reducing antioxidant power (FRAP), $5 \mathrm{~g}$ of samples were extracted with a mixture containing acetone, water and acetic acid (70:29.5:0.5 v:v:v) (Kähkönen et al., 2001). The total phenolics content was measured using the Folin-Ciocalteu's phenol reagent, as described by Scalbert et al. (1989). Gallic acid was used as standard and the results were expressed as $\mathrm{mg}$ of gallic acid equivalent (GAE) $g^{-1}$ FW. FRAP was determined by following the method of Benzie and Strain (1996) and the results were expressed as $\mu \mathrm{mol}$ $\mathrm{ASC}^{-1} \mathrm{FW}$.

\subsection{Statistical analysis}

Statistical analysis was carried out using the software package SPSS v21.0 (SPSS Inc., Chicago, USA) and the comparison of averages of each treatment was based on the analysis of variance (One-Way ANOVA) according to Duncan's multiple range test at significance level $5 \%(P<0.05)$. The data presented are means \pm standard error (SE) of four replications (four harvests).

\section{Results and discussion}

\subsection{Irrigation water quality}

The average values of physico-chemical and microbial properties of the two water sources used for the strawberry plants' irrigation met irrigation water quality standards according to FAO's guidelines (Ayers and Westcot, 1985), as shown in Table 1. The EC of PW was found in the range where no restrictions should be applied for irrigation, whereas the EC of WW was in the range where slight to moderate restrictions are applied for its reuse for irrigation. The two irrigation water sources were alkaline with similar $\mathrm{pH}$ values (8.3), while WW had significantly higher $\mathrm{Cl}^{-}$concentration compared to PW. In addition, the microbiological examination uncovered the absence of Escherichia coli and helminths eggs from both the water sources applied for the irrigation of strawberry plants. Moreover, the tertiary treated WW used in this study was fully in line with both the WHO (WHO, 2006) and the USEPA (US Environmental Protection Agency, 2012) guidelines for WW reuse in agriculture. The high quality of the tertiary treated WW used in this study may be attributed to the sewage origin (mostly households), the tertiary treatment through MBR and the UV disinfection, 
Table 2

Effects of treated wastewater effluent and potable water applied with discrete techniques for the irrigation of strawberry plants on fruits' productivity and marketability.

\begin{tabular}{|c|c|c|c|c|c|c|}
\hline \multirow[t]{2}{*}{ Variable } & \multicolumn{6}{|c|}{ Water source and irrigation technique } \\
\hline & PW-DR & WW-DR & PW-SPR & WW-SPR & PW-DRPM & WW-DRPM \\
\hline Number of harvested fruits per plant & 6.3 & 5.9 & 5.8 & 5.3 & 4.7 & 7.7 \\
\hline Marketable fruits' weight $(\mathrm{g})$ & $17.3 \pm 0.7 \mathrm{a}$ & $15.1 \pm 0.5 \mathrm{ab}$ & $17.4 \pm 0.6 \mathrm{a}$ & $15.3 \pm 0.6 \mathrm{ab}$ & $17.7 \pm 0.9 \mathrm{a}$ & $13.5 \pm 0.5 b$ \\
\hline Unmarketable (deformed) fruits' weight (g) & $12.2 \pm 1.0 \mathrm{a}$ & $11.0 \pm 1.1 \mathrm{a}$ & $11.8 \pm 1.1 \mathrm{a}$ & $8.3 \pm 0.8 \mathrm{~b}$ & $10.2 \pm 1.0 \mathrm{ab}$ & $9.3 \pm 0.6 \mathrm{~b}$ \\
\hline$\%$ marketable fruits & $77.5 \pm 5.7$ & $79.7 \pm 9.1$ & $78.5 \pm 5.5$ & $87.4 \pm 4.9$ & $71.4 \pm 6.0$ & $76.6 \pm 8.1$ \\
\hline
\end{tabular}

Mean values with different letters within each variable are significantly different according to Duncan's multiple range test $(\mathrm{P}<0.005)$.

Table 3

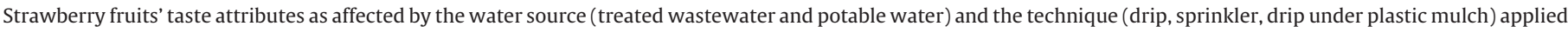
for the plants' irrigation.

\begin{tabular}{|c|c|c|c|c|c|c|}
\hline \multirow[t]{2}{*}{ Parameter } & \multicolumn{6}{|c|}{ Water source and irrigation technique } \\
\hline & PW-DR & WW-DR & PW-SPR & WW-SPR & PW-DRPM & WW-DRPM \\
\hline Dry matter (\%) & $7.16 \pm 0.01$ & $7.19 \pm 0.12$ & $7.09 \pm 0.05$ & $6.92 \pm 0.41$ & $7.68 \pm 0.27$ & $7.24 \pm 0.09$ \\
\hline $\mathrm{pH}$ & $3.59 \pm 0.04$ & $3.56 \pm 0.05$ & $3.53 \pm 0.04$ & $3.59 \pm 0.05$ & $3.54 \pm 0.03$ & $3.57 \pm 0.04$ \\
\hline Soluble solids (SS) $\left({ }^{\circ}\right.$ Brix $)$ & $6.60 \pm 0.14$ & $6.48 \pm 0.25$ & $6.31 \pm 0.20$ & $6.30 \pm 0.47$ & $7.21 \pm 0.34$ & $7.10 \pm 0.19$ \\
\hline Tritratable acididy (TA) (\% Citric acid) & $0.88 \pm 0.04$ & $0.85 \pm 0.04$ & $0.83 \pm 0.06$ & $0.80 \pm 0.04$ & $0.90 \pm 0.05$ & $0.90 \pm 0.05$ \\
\hline SS/TA & $7.50 \pm 0.21$ & $7.62 \pm 0.31$ & $7.60 \pm 0.59$ & $7.87 \pm 0.18$ & $8.01 \pm 0.44$ & $7.88 \pm 0.93$ \\
\hline
\end{tabular}

Mean values with different letters within each parameter are significantly different according to Duncan's multiple range test $(\mathrm{P}<0.005)$.

and the absence of heavy industry in Cyprus. On the other hand, the low heavy metals content in potable water may be due to the use of desalinated seawater for water supply.

\subsection{Effects of the irrigation treatments on the crops productivity and fruit marketability and quality}

Plants irrigated with WW using drips covered under plastic mulch (WW-DRPM) produced the highest number of fruits. The order of plant productivity among treatments was WWDRPM $>$ PW-DR $>$ WW-DR $>$ PW-SPR $>$ WW-SPR $>$ PW-DRPM. As shown in Table 2, plants irrigated with potable water with either drips (PW-DR) or sprinklers (PW-SPR) produced slightly higher number of fruits per plant compared to the respective wastewaterirrigated plants (WW-DR and WW-SPR, respectively). Adversely, wastewater-irrigated plants produced significantly higher number of fruits per plant compared to PW irrigated ones, when irrigated with drips under plastic mulch. This could be possibly attributed to the plastic mulching-mediated constant moisture content and higher temperature of the soil in the WW-DRPM treatment, which may favor higher microbial biomass in the soil thus ensuring more complete nitrification of the higher total $\mathrm{N}$ content of WW compare to PW; thus resulting in increased fruit set and yield (Kasirajan and Ngouajio, 2012). Moreover, the percentage of marketable fruits was not affected by the treatments applied. Marketable fruits in WW-DRPM treatments had a significantly lower weight compared to the ones of other treatments, probably because of the higher productivity recorded in this treatment. The unmarketable fruits' weight was found lower in WW-DRPM and WW-SPR treatments compared to other treatments (Table 2). Similar results were obtained regarding the productivity of tomato plants grown in field and drip irrigated with the same WW, as well as with WW treated with slow sand filtration and disinfected by chlorination, as the fruit mean weight, maximum diameter and the total number of fruits harvested from WW-irrigated tomato plants were not significantly different from the ones form control tubewell water irrigated plants (Christou et al., 2014b). The use of poorly treated WW or WW which contains considerable nutrient content and total suspended solids compared to the tertiary treated effluent used in this study, may result to significantly higher harvest (Mañas et al., 2009; Cirelli et al., 2012).

Results also revealed that treatments had no significant effects on strawberry fruit quality and taste, as the percentage of dry mat- ter, $\mathrm{pH}, \mathrm{SS}, \mathrm{TA}$ and SS/TA ratio displayed no significant differences among all treatments (Table 3 ). More precisely, values among all treatments averaged $7.21,3.56,6.67,0.86$ and 7.75 for dry mater (\%), $\mathrm{pH}, \mathrm{SS}, \mathrm{TA}$ and SS/TA, respectively, being in accordance with previous reported results regarding the quality attributes of strawberry fruits and of the Camarosa cultivar in particular (Cordenunsi et al., 2003; Roussos et al., 2009; Neocleous, 2012). Noteworthy, the fruits in all treatments showed an SS/TA ratio adequate to achieve best quality (Cordenunsi et al., 2003). However, the quality attributes of agricultural produce may be affected by the quality of the WW applied for agricultural crops irrigation. Al-Lahham et al. (2003) reported that WW (treated by activated sludge-extended aeration) irrigation of tomatoes under field conditions resulted in the significant decrease of fruits' SS, firmness and weight loss. In contrast, Bedbabis et al. (2015) showed that the standard quality indices of virgin olive oil and oil content were not significantly affected following 10 years of irrigation with WW treated with biological treatment process.

In order to assess the effects of irrigation treatments on the antioxidant capacity of strawberry fruits, the content of ascorbic acid and the total phenolics and total anthocyanin, as well as the FRAP values, were estimated. As shown in Table 4, the content of the antioxidant compounds assayed was not affected by the various treatments. The values obtained from the FRAP assay, an indicator of the total antioxidant power of fruits (Benzie and Strain, 1996), further corroborate the above results, as no treatmentmediated effects were revealed on total antioxidant capacity. The conservation of antioxidant capacity and antioxidant molecules concentration in WW-irrigated treatments in levels similar to the respective control treatments may be due to the high quality of the WW used in this study, as irrigation of lettuce, turnip and tomato plants with low quality WW (industrial) was found to significantly induce the activity of antioxidant enzymes and the overall antioxidant capacity of produce, as a result of heavy metal induced stress responses (Hashem et al., 2013; Naaz and Pandey, 2010)

Effects of the irrigation treatments on the strawberry fruit safety (Heavy metal content and microbial contamination)

Irrigation treatments displayed no significant effects on $\mathrm{Cu}, \mathrm{Zn}$, Co and Ni concentrations in strawberry fruits. Adversely, Mn concentration in strawberry fruits was significantly affected by the water source applied and the technique used for the irrigation 
Table 4

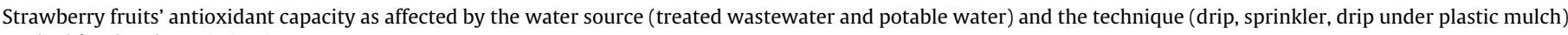
applied for the plants' irrigation.

\begin{tabular}{|c|c|c|c|c|c|c|}
\hline \multirow[t]{2}{*}{ Parameter } & \multicolumn{6}{|c|}{ Water source and irrigation technique } \\
\hline & PW-DR & WW-DR & PW-SPR & WW-SPR & PW-DRPM & WW-DRPM \\
\hline Ascorbic acid (mg ASC $\left.100 \mathrm{~g}^{-1} \mathrm{FW}\right)$ & $28.31 \pm 3.38$ & $30.67 \pm 2.32$ & $32.38 \pm 1.22$ & $30.15 \pm 3.33$ & $33.09 \pm 2.29$ & $30.91 \pm 2.07$ \\
\hline Antioxidant capacity (FRAP values) ( $\mu$ mol ASC g ${ }^{-1} \mathrm{FW}$ ) & $14.82 \pm 1.10$ & $16.43 \pm 1.51$ & $15.69 \pm 1.75$ & $15.75 \pm 0.81$ & $18.44 \pm 0.71$ & $15.92 \pm 0.89$ \\
\hline Total phenolics content (mg GAE g $\left.{ }^{-1} \mathrm{FW}\right)$ & $1.88 \pm 0.13 b$ & $2.13 \pm 0.15 \mathrm{ab}$ & $1.96 \pm 0.08 \mathrm{ab}$ & $2.06 \pm 0.09 \mathrm{ab}$ & $2.39 \pm 0.09 \mathrm{a}$ & $2.07 \pm 0.06 \mathrm{ab}$ \\
\hline Total anthocyanin (mg P-3-G equivalents $100 \mathrm{~g}^{-1} \mathrm{FW}$ ) & $26.49 \pm 1.44$ & $26.00 \pm 2.10$ & $23.45 \pm 2.51$ & $26.22 \pm 2.73$ & $22.62 \pm 2.73$ & $25.79 \pm 1.20$ \\
\hline
\end{tabular}

Mean values with different letters within each parameter are significantly different according to Duncan's multiple range test $(\mathrm{P}<0.005)$.

Table 5

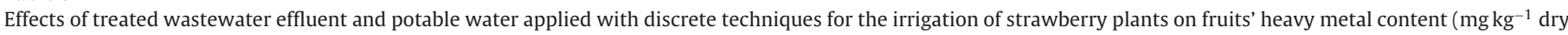
weight).

\begin{tabular}{|c|c|c|c|c|c|}
\hline \multirow[t]{2}{*}{ Parameter } & \multicolumn{5}{|l|}{ Heavy metal } \\
\hline & $\mathrm{Cu}$ & $\mathrm{Zn}$ & Mn & Co & $\mathrm{Ni}$ \\
\hline PW-DR & $3.48 \pm 0.50$ & $11.38 \pm 0.50$ & $28.63 \pm 0.85 b$ & $0.55 \pm 0.28$ & $3.49 \pm 0.29$ \\
\hline WW-DR & $3.07 \pm 0.73$ & $13.25 \pm 0.66$ & $31.75 \pm 1.07 \mathrm{ab}$ & $1.17 \pm 0.38$ & $4.85 \pm 1.01$ \\
\hline PW-SPR & $2.65 \pm 0.39$ & $11.74 \pm 1.07$ & $27.40 \pm 1.26 \mathrm{~b}$ & $0.65 \pm 0.24$ & $3.67 \pm 0.68$ \\
\hline WW-SPR & $2.78 \pm 0.35$ & $13.63 \pm 0.39$ & $33.85 \pm 0.76 a$ & $0.82 \pm 0.32$ & $5.23 \pm 0.86$ \\
\hline PW-DRPM & $2.58 \pm 0.51$ & $11.29 \pm 1.22$ & $33.78 \pm 1.29 \mathrm{a}$ & $1.06 \pm 0.48$ & $4.59 \pm 1.34$ \\
\hline WW-DRPM & $3.67 \pm 0.73$ & $16.65 \pm 5.37$ & $28.85 \pm 1.12 b$ & $1.04 \pm 0.59$ & $4.73 \pm 0.46$ \\
\hline MPL & 73.3 & 99.4 & & & 67.9 \\
\hline
\end{tabular}

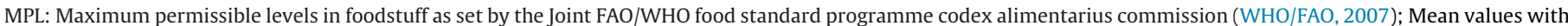
different letters within each parameter are significantly different according to Duncan's multiple range test $(P<0.005)$

Table 6

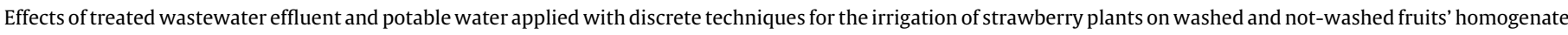
microbiological load.

\begin{tabular}{|c|c|c|c|c|c|c|c|}
\hline \multirow[t]{2}{*}{ Microbial \& pathogen test } & \multirow[t]{2}{*}{ Treatment of sample } & \multicolumn{6}{|c|}{ Water source and irrigation technique } \\
\hline & & PW-DR & WW-DR & PW-SPR & WW-SPR & PW-DRPM & WW-DRPM \\
\hline \multirow[t]{2}{*}{$\mathrm{APC}\left(\mathrm{CFU} \mathrm{g}^{-1}\right)$} & NW & $467 \pm 176 \mathrm{~d}$ & $1000 \pm 100 \mathrm{~d}$ & $2000 \pm 321$ bc & $933 \pm 88 d$ & $5700 \pm 208 a$ & $6167 \pm 176 a$ \\
\hline & W & $400 \pm 58 d$ & $633 \pm 120 \mathrm{~d}$ & $1700 \pm 265 c$ & $566 \pm 88 \mathrm{~d}$ & $5300 \pm 58 \mathrm{a}$ & $2833 \pm 260 b$ \\
\hline \multirow{2}{*}{$\mathrm{TC}\left(\mathrm{CFU} \mathrm{g}^{-1}\right)$} & NW & $\mathrm{ND}^{\mathrm{a}}$ & ND & ND & ND & ND & ND \\
\hline & $\mathrm{W}$ & ND & ND & ND & ND & ND & ND \\
\hline \multirow[t]{2}{*}{ Escherichia coli $\left(\mathrm{CFU} \mathrm{g}^{-1}\right)$} & NW & absent & absent & absent & absent & absent & absent \\
\hline & W & absent & absent & absent & absent & absent & absent \\
\hline \multirow[t]{2}{*}{ Salmonella spp.(CFU g $\left.{ }^{-1}\right)$} & NW & absent & absent & absent & absent & absent & absent \\
\hline & W & absent & absent & absent & absent & absent & absent \\
\hline \multirow[t]{2}{*}{ Listeria spp.(CFU g $\left.{ }^{-1}\right)$} & NW & absent & absent & absent & absent & absent & absent \\
\hline & $\mathrm{W}$ & absent & absent & absent & absent & absent & absent \\
\hline
\end{tabular}

Data are means \pm SE of four replications; APC, aerobic plate count; NW, Not washed; W, Washed with tap water; TC, Total coliform.

a Not detected $\left(<10 \mathrm{CFU} \mathrm{g}{ }^{-1}\right)$; APC mean values with different letters are significantly different according to Duncan's multiple range test $(\mathrm{P}<0.005)$.

of strawberry plants (Table 5). Fruits harvested from plants in WW-SPR and PW-DRPM treatments displayed significantly higher Mn concentration compared to the ones harvested from PW-DR, PW-SPR and WW-DRPM treatments (Table 5). Moreover, Cu concentrations ranged from 2.58 to $3.67 \mathrm{mg} \mathrm{kg}^{-1}$ dry weight (DW), $\mathrm{Zn}$ from 11.29 to $16.65 \mathrm{mg} \mathrm{kg}^{-1} \mathrm{DW}$, Mn from 27.40 to $33.85 \mathrm{mg} \mathrm{kg}^{-1}$ DW, Co from 0.55 to $1.17 \mathrm{mg} \mathrm{kg}^{-1} \mathrm{DW}$ and $\mathrm{Ni}$ from 3.49 to $5.23 \mathrm{mg} \mathrm{kg}^{-1} \mathrm{DW}$. The quantified $\mathrm{Cu}, \mathrm{Zn}$ and Ni concentrations were below the maximum permissible limits (MPLs) (73.3, 99.4 and $67.7 \mathrm{mg} \mathrm{kg}^{-1} \mathrm{DW}$, respectively) set by the WHO/FAO Codex Committee on Food Hygiene (WHO/FAO, 2007). Similarly, the reuse of tertiary treated WW (through MBR) resulted in low, within the MPL, heavy metal content in tomato fruits (Christou et al., 2014b), as well as in tomatoes, fennel and lettuce (Lonigro et al., 2007). However, the reuse of low quality WW (poorly treated, industrial), either on short- or long-term basis, may result to the bioaccumulation of heavy metals in agricultural produce in levels exceeding MPLs, posing serious public health implications (Khan et al., 2008; Naaz and Pandey, 2010; Singh et al., 2010; Hashem et al., 2013).

In order to further assess the safety of WW irrigation with the techniques used in this study, the level of microbial contamination (APC, TC), as well as the presence of Escherichia coli, Salmonella spp. and Listeria spp. in the fruit homogenate of washed and notwashed fruits, were evaluated. It is worth noting that TC, as well as Escherichia coli, Salmonella spp. and Listeria spp. were not detected in the fruits' homogenates of all treatments (Table 6). Interestingly, the absence of such microbial contaminants was also verified in lettuce leaf tissues sampled from plants grown simultaneously with strawberries and undergone the same experimental treatments (data not shown). Such results may be explained by the absence of these contaminants from the WW used in this study, as MBR and UV disinfection applied in the WW treatment plant supplied the studied WW may successfully removed microbial contaminants from the treated effluent. The absence of the examined microbial contaminants from non-washed strawberry fruits homogenates highlights the safety of the use of both drips and sprinklers for the irrigation of strawberries, as no internalization of such contaminants was found, even when fruits were in direct contact with WW (sprinkler irrigation) or WW-irrigated soil (drip irrigation). Aiello et al. (2007) reported negligible microbial contamination (E. coli, Faecal Streptococci, Salmonella spp.) of WW-irrigated tomato fruits, despite the increased microbial contamination on the soil surface, further corroborating our results. The safe reuse of WW, either with sprinklers, farrow or subsurface drip irrigation, for the irri- 
gation of potatoes (Forslund et al., 2010), tomatoes (Forslund et al., 2012; Orlofsky et al., 2016) and fennel and lettuce (Lonigro et al., 2016), was also reported. The assay of APC revealed that the aerobic, mesophilic microorganisms were predominantly found in fruits harvested from plants irrigated with drips covered with plastic mulch, and that washing the fruits with tap water failed to thoroughly remove these microorganisms. The APC levels in strawberry fruit in our experiment could be attributed to the external environmental contamination, as typical wildlife constitute an important source of faecal contamination (Frank, 2001; Forslund et al., 2012).

To our knowledge, this is the first study to assess both the heavy metal content and the microbial contamination of wastewaterirrigated strawberries and the results obtained highlighted that the WW used in this study can be considered as safe for the irrigation of strawberry crops, regardless of the irrigation technique applied.

\section{Conclusions}

Results revealed that the treated WW under study caused no significant modulations on strawberry crops' productivity and fruits quality attributes as compared to potable water, regardless of the irrigation technique applied. More precisely, no statistically significant effects on fruit marketability (\% marketable fruits), taste and quality (pH, SS, TA, SS/TA), and antioxidant capacity (ASC concentration, FRAP, total phenolics and total anthocyanin) were shown among all irrigation treatments applied, either concerned WW or PW irrigation. Slight differences among treatments concerned the higher number of fruits per plant produced in WW-DRPM treatment as compared to others; however fruits' weight was significantly lower. Moreover, heavy metal (Cu, Zn, Mn, Co, Ni) content was below the MPLs, whereas, Escherichia coli, Salmonella spp. and Listeria spp. were absent from all harvested fruits. Overall, obtained results highlight that good quality wastewater is a safe and viable alternative for the irrigation of strawberry crops, even with sprinklers, though long-term studies are need to confirm the validity of these evidence.

\section{Acknowledgements}

The authors wish to thank all the personnel of the Cyprus Agricultural Research Institute involved in the study for their excellent technical assistance. This study was undertaken in collaboration with Nireas-International Water Research Center of the University of Cyprus and supported by Cyprus Agricultural Research Institute Internal Grant to Anastasis Christou.

\section{References}

AOAC, 2005. Official Methods of Analysis of the Association of Official Analytical Chemists, 18th ed. AOAC Press, Washington DC.

APHA, 1998. Standard Method for the Examination of Water and Wastewater, 20th ed. APHA, AWWA and WEF, Washington, DC.

Adam, V., Kizek, R., 2012. Metal ions in cause, progression, treatment and diagnosis of genetic disorders, metabolic diseases and cancer. Curr. Drug Metab. 13, 236

Aiello, R., Cirelli, G.L., Consoli, S., 2007. Effects of reclaimed wastewater irrigation on soil and tomato fruits: a case study in Sicily (Italy). Agr. Water Manage. 93, 65-72.

Al-Lahham, O., El Assi, N.M., Fayyad, M., 2003. Impact of treated wastewater irrigation on quality attributes and contamination of tomato fruit. Agric. Water Manage. 61, 51-62.

Al-Lahham, O., El Assi, N.M., Fayyad, M., 2007. Translocation of heavy metals to tomato (Solanum lycopersicom L.) fruit irrigated with treated wastewater. Sci. Hortic. 113, 250-254.

Angelakis, A.N., Durham, B., 2008. Water recycling and reuse in EUREAU countries: trends and challenges. Desalination 218, 3-12.

Ayers, R.S., Westcot, D.W. (Eds.), 1985. Water Quality for Irrigation. FAO, Rome.

Bahri, A., 1999. Agricultural reuse of wastewater and global water management. Water Sci. Technol. 40, 339-346.

Bedbabis, S., Trigui, D., Ben Ahmed, C., Clodoveo, M.L., Camposeo, S., Vivaldi, G.A., Ben Rouina, B., 2015. Long-terms effects of irrigation with treated municipal wastewater on soil: yield and olive oil quality. Agric. Water Manage. 160, $14-21$.

Benzie, I.F.F., Strain, J.J., 1996. The ferric reducing ability of plasma (FRAP) as a measure of antioxidant power. The FRAP Assay. Anal. Biochem. 239, 70-76.

Bernstein, N., 2011. Potential for contamination of crops by microbial human pathogens introduced into the soil by irrigation with treated effluent. Israel J. Plant Sci. 59, 115-123.

Bixio, D., Thoeye, C., De Koning, J., Joksimovic, D., Savic, D., Wintgens, T., Melin, T. 2006. Wastewater reuse in europe. Desalination 187, 89-101.

Brissaud, F., 2008. Criteria for water recycling and reuse in the Mediterranean countries. Desalination 218, 24-33.

Christou, A., Eliadou, E., Michael, C., Hapeshi, E., Fatta-Kassinos, D., 2014a. Assessment of long-term wastewater irrigation impacts on the soil geochemical properties and the bioaccumulation of heavy metals to the agricultural products. Environ. Monit. Assess. 186, 4857-4870.

Christou, A., Maratheftis, G., Eliadou, E., Michael, C., Hapeshi, E., Fatta-Kassinos, D., 2014 b. Impact assessment of the reuse of two discrete treated wastewaters for the irrigation of tomato crop on the soil geochemical properties: fruit safety and crop productivity. Agric. Ecosyst. Environ. 192, 105-114.

Chu, J., Chen, J., Wang, C., Fu, P., 2004. Wastewater reuse potential analysis: implications for China's water resources management. Water Res. 38, 2746-2756.

Cirelli, G.L., Consoli, S., Licciardello, F., Aiello, R., Giuffrida, F., Leonardi, C., 2012. Treated municipal wastewater reuse in vegetable production. Agric. Water Manage. 104, 163-170.

Cordenunsi, B.R., Nascimento, J.R.O., Lajolo, F.M., 2003. Physico-chemical changes related to quality of five strawberry fruit cultivars during cool-storage. Food Chem. 83, 167-173.

Fatta-Kassinos, D., Kalavrouziotis, I.K., Koukoulakis, P.H., Vasquez, M.I., 2011. The risks associated with wastewater reuse and xenobiotics in the agroecological environment. Sci. Total Environ. 409, 3555-3563.

Forslund, A., Ensink, J.H.J., Battilani, A., Kljujev, I., Gola, S., Raicevic, V., Jovanovic, Z., Stikic, R., Sandei, L., Fletcher, T., Dalsgaard, A., 2010. Faecal contamination and hygiene aspect associated with the use of treated wastewater and canal water for irrigation of potatoes (Solanum tuberosum). Agric. Water Manage. 98, 440-450.

Forslund, A., Ensink, J.H.J., Markussen, B., Battilani, A., Psarras, G., Gola, S., Sandei, L., Fletcher, T., Dalsgaard, A., 2012. Escherichia coli contamination and health aspects of soil and tomatoes (Solanum lycopersicum L:) subsurface drip irrigated with on-site treated domestic wastewater. Water Res. 46, 5917-5934.

Frank, J.F., 2001. Microbial Attachment to Food and Food Contact Surfaces Advances in Food and Nutrition Research, vol. 43. Academic Press, pp. 319-370.

Hamilton, A.J., Stagnitti, F., Premier, R., Boland, A.-M., Hale, G., 2006a. Quantitative microbial risk assessment models for consumption of raw vegetables irrigated with reclaimed water. Appl. Environ. Microbiol. 72, 3284-3290.

Hamilton, A.J., Stagnitti, F.S., Premier, R., Boland, A.M., 2006b. Is the risk of illness through consuming vegetables irrigated with reclaimed wastewater different for different population groups? Water Sci. Technol. 54, 379-386.

Hamilton, A.J., Stagnitti, F., Xiong, X., Kreidl, S.L., Benke, K.K., Maher, P., 2007. Wastewater irrigation: the state of play. Vadose Zone J. 6, 823-840.

Hashem, H.A., Hassanein, R.A., El-Deep, M.H., Shouman, A.I., 2013. Irrigation with industrial wastewater activates antioxidant system and osmoprotectant accumulation in lettuce: turnip and tomato plants. Ecotoxicol. Environ. Saf. 95, $144-152$.

Kähkönen, M.P., Hopia, A.I., Heinonen, M., 2001. Berry phenolics and their antioxidant activity. J. Agric. Food Chem. 49, 4076-4082.

Kasirajan, S., Ngouajio, M., 2012. Polyethylene and biodegradable mulches for agricultural applications: a review. Agron. Sustain. Dev 32, 501-529.

Khan, S., Cao, Q., Zheng, Y.M., Huang, Y.Z., Zhu, Y.G., 2008. Health risks of heavy metals in contaminated soils and food crops irrigated with wastewater in Beijing. China. Environ. Pollut. 152, 686-692.

Khurana, M.P.S., Singh, P., 2012. Waste water use in crop production: a review. Resour. Environ. 2, 116-131

Li, P., Wang, X., Allinson, G., Li, X., Xiong, X., 2009. Risk assessment of heavy metals in soil previously irrigated with industrial wastewater in Shenyang, China. J. Hazard. Mat. 161, 516-521.

Lonigro, A., Rubino, P., Brandonisio, O., Spinelli, R., Pollice, A., Laera, G., 2007. Vegetable crop irrigation with tertiary filtered municipal wastewater. Plant Biosyst. 141, 275-281.

Lonigro, A., Rubino, P., Lacasella, V., Montemurro, N., 2016. Faecal pollution on vegetables and soil drip irrigated with treated municipal wastewaters. Agric. Water Manag. (in press).

Mañas, P., Castro, E., de las Heras, J., 2009. Irrigation with treated wastewater Effects on soil, lettuce (Lactuca sativa L.) crop and dynamics of microorganisms. J. Environ. Sci. Health A. 44, 1261-1273.

Mapanda, F., Mangwayana, E.N., Nyamangara, J., Giller, K.E., 2005. The effect of long-term irrigation using wastewater on heavy metal contents of soils under vegetables in Harare, Zimbabwe. Agric. Ecosyst. Environ. 107, 151-165.

Mara, D.D., Sleigh, P.A., Blumenthal, U.J., Carr, R.M., 2007. Health risks in wastewater irrigation: comparing estimates from quantitative microbial risk analyses and epidemiological studies. J. Water Health 5, 39-50.

Mesa-Jurado, M.A., Martin-Ortega, J., Ruto, E., Berbel, J., 2012. The economic value of guaranteed water supply for irrigation under scarcity conditions. Agric. Water Manage. 113, 10-18. 
Milano, M., Ruelland, D., Fernandez, S., Dezetter, A., Fabre, J., Servat, E., 2012. Facing climatic and anthropogenic changes in the Mediterranean basin: what will be the medium-term impact on water stress? C.R. Geosci. 344, 432-440.

Mok, H.-F., Barker, S.F., Hamilton, A.J., 2014. A probabilistic quantitative microbial risk assessment model of norovirus disease burden from wastewater irrigation of vegetables in Shepparton, Australia. Water Res. 54, 347-362.

Muchuweti, M., Birkett, J.W., Chinyanga, E., Zvauya, R., Scrimshaw, M.D., Lester, J.N., 2006. Heavy metal content of vegetables irrigated with mixtures of wastewater and sewage sludge in Zimbabwe: implications for human health. Agric. Ecosyst. Environ. 112, 41-48.

Naaz, S., Pandey, S.N., 2010. Effects of industrial waste water on heavy metal accumulation: growth and biochemical responses of lettuce (Lactuca sativa L.). J. Environ. Biol. 31, 273-276.

Neocleous, D., 2012. Effects of cultivars and coco-substrates on soilless strawberry production in Cyprus. J. Berry Res. 2, 207-213.

Orlofsky, E., Bernstein, N., Sacks, M., Vonshak, A., Benami, M., Kundu, A., Maki, M., Smith, W., Wuertz, S., Shapiro, K., Gillor, O., 2016. Comparable levels of microbial contamination in soil and on tomato crops after drip irrigation with treated wastewater or potable water. Agric. Ecosyst. Environ. 215, 140-150.

Palese, A.M., Pasquale, V., Celano, G., Figliuolo, G., Masi, S., Xiloyannis, C., 2009. Irrigation of olive groves in Southern Italy with treated municipal wastewater: effects on microbiological quality of soil and fruits. Agric. Ecosyst. Environ. 129, 43-51

Petterson, S.R., Ashbolt, N.J., Sharma, A., 2001. Microbial risks from wastewater irrigation of salad crops: a screening-level risk assessment. Water Environ. Res. 73, 667-672.

Rajaganapathy, V., Xavier, F., Sreekumar, D., Mandal, P.K., 2011. Heavy metal contamination in soil, water and fodder and their presence in livestock and products: a review. J. Environ. Sci. Technol. 4, 234-249.
Roussos, P.A., Denaxa, N.K., Damvakaris, T., 2009. Strawberry fruit quality attributes after application of plant growth stimulating compounds. Sci. Horticul. 119, 138-146.

Scalbert, A., Monties, B., Janin, G., 1989. Tannins in wood: comparison of different estimation methods. J. Agric. Food Chem. 37, 1324-1329.

Singh, K.P., Mohan, D., Sinha, S., Dalwani, R., 2004. Impact assessment of treated/untreated wastewater toxicants discharged by sewage treatment plants on health, agricultural, and environmental quality in the wastewater disposal area. Chemosphere 55, 227-255.

Singh, A., Sharma, R.K., Agrawal, M., Marshall, F.M., 2010. Health risk assessment of heavy metals via dietary intake of foodstuffs from the wastewater irrigated site of a dry tropical area of India. Food Chem. Toxicol. 48, 611-619.

Szkup-Jablonska, M., Karakiewicz, B., Grochans, E., Jurczak, A., Nowak-Starz, G., Rotter, I., Prokopowicz, A., 2012. Effects of blood lead and cadmium levels on the functioning of children with behaviour disorders in the family environment. Ann. Agric. Environ. Med. 19, 241-246.

U.S. Environmental Protection Agency, 2012. Guidelines for Water Reuse. United States Environmental Protection Agency.

WHO, 2006. WHO guidelines for the safe use of wastewater, excreta and greywater. Wastewater Use in Agriculture, vol. 2. World Health Organisation, Geneva Switzerland.

WHO/FAO, 2007. Joint FAO/WHO food standard programme codex alimentarius commission, 13th Session. Report of the thirty eight session of the codex committee on food hygiene. Houston, United States of America, ALINORM $07 / 30 / 13$.

Xu, J., Wu, L., Chang, A.C., Zhang, Y., 2010. Impact of long-term reclaimed wastewater irrigation on agricultural soils: a preliminary assessment. J. Hazard. Mater. 183, 780-786. 